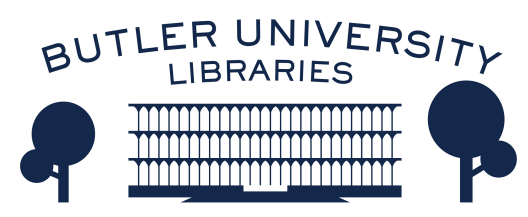

Journal of Hindu-Christian Studies

Volume 11

Article 6

January 1998

\title{
Speaking of the Hindu Diaspora in Australia
}

Purushottama Bilimoria

Follow this and additional works at: https://digitalcommons.butler.edu/jhcs

Part of the Religion Commons

\section{Recommended Citation}

Bilimoria, Purushottama (1998) "Speaking of the Hindu Diaspora in Australia," Journal of Hindu-Christian Studies: Vol. 11, Article 6.

Available at: https://doi.org/10.7825/2164-6279.1179

The Journal of Hindu-Christian Studies is a publication of the Society for Hindu-Christian Studies. The digital version is made available by Digital Commons @ Butler University. For questions about the Journal or the Society, please contact cbauman@butler.edu. For more information about Digital Commons @ Butler University, please contact digitalscholarship@butler.edu. 


\title{
Speaking of the Hindu Diaspora in Australia
}

\author{
Purushottama Bilimoria \\ Social Inquiry, Deakin University \\ Philosophy, University of Melbourne
}

WHAT ARE THE distinctive characteristics of the "Diaspora Hindus" who turned up during the different phases in the Australian landscape? To address this question, this essay will briefly discuss the early, colonial, post-independent, and more recent phases corresponding to patterns in migration, settlement, and temple culture of Australian Hindus, drawing on the history of their reception in the host society alongside other data, from the 1857 to 1996 national censuses. $^{1}$

\section{Early History}

Hindus had long fantasized about the vast (un)inhabited landmass that lay farthest south of the dreaded seas where civilization ended. While Java-based Hindus had trading contacts with Moluccus and Timor, there is only anecdotal evidence of their presence dakshinahidvipavāt. ${ }^{2}$

The "coolie Hindoo"

On board the first few fleets that brought white settlers and convicts to terra australis, from 1787-1823, there were a few Indian crews, and others came later as labourers or as convicts. As the hinterlands opened up there were renewed calls for recruitment of Indian labourers, although misgivings about the effects of "paganism" and "colour" of the caste Hindus remained rife. ${ }^{3}$ But an exBritish planter from India argued in favour of Hindu labourers because they were "not addicted to opium, wine and spirit" and worked hard, equal in some respects to Europeans. ${ }^{4}$ In 1837 he recruited some 40 "Hindoo" labourers to work in the fields; most were Dhangar tribal people from Chotanagpur region.
Anxieties about the likely treatment of Hindus in Australia in view of their practice of "idolatry" and "caste evils" did not deter private entrepreneurs from sponsoring emigration of Indian "coolies". But fears of a mass exodus of "Hindoos", led the colonial Indian government to pass the Indian Emigration Act 1839. Henceforth only a few Indians migrated as itinerant merchants, and small shipments under private arrangements continued throughout the $1840 \mathrm{~s}$ and $1850 \mathrm{~s} .{ }^{5}$ These latter recruits comprised larger number of Hindus, some of higher caste groups. The 1857 census showed that Victoria alone had 277 persons of Indian or "Hindoo race". (Race was a common classification to register and colour and religious roots.)

The "Hindoo hawker"

The next wave of Indians came with Pathans from Punjab, Sind, and Frontier Provinces; they were Indian nationals classified as "Hindoos". Some indeed were Hindus, the rest were Punjabi Muslims and Sikhs. They worked as camel-drivers or servants on caravanserais. Later, some ventured to gold mines in Victoria and a few to pastoral projects. The men married local white or aboriginal women, but otherwise "close association with the infidel community" was discouraged. (Their "half-caste" children were not allowed to marry back into AngloChristian families. ${ }^{6}$ )

Hindus along with Sikh Pathans became hawkers and pedlars in rural outposts carting their bundle of wares, silk, and utensils which they sold door to door. When a Hindu or Sikh among them died, he would be cremated in the open eucalyptus-pyre. 
Most returned to the subcontinent to retire; some continued their small trading interests or took casual jobs. The early signs of public reaction to the presence of Hindus appeared in 1893. A news magazine report chided at the "niggardliness" of the hawkers and "the wretched manner in which Hindus and Mahometans live" only to hoard a "pile" (of money) to take back to their own country. While they begged for tea and tobacco, they were less frugal with drinks, under whose influence "they seem either horribly dangerous or irredeemably nasty". 7

In sum, Indian/Hindu immigration was a mixture of banished Rāmas, "coolie" recruits, domestic servants, farm-hands, and plantation labourers, to camel-drivers and hawkers. Estranged from their families, a good few eventually left for their homeland. The ethnic-religious identity also came to prevail among the few Indians. Thus, a Hindu merchant, Shri Pammamull, who came from the Sind region as an opal polisher, gradually built a family opal trade that has prosperously continued with his third to fourth generation descendants, who too remain as devout Hindus, contributing generously to Hindu-Indian causes. ${ }^{8}$

White Australia Policy and the absented Hindu

The official barrage continued over immigration of Indians, indeed of all Asians. This culminated in the Immigration Restriction Act 1901, effectively heralding the "White Australia" policy. The supreme exclusivity of the "white race", with its supporting Christian base, was repeated by numerous leaders in Australia over several decades. ${ }^{9}$ Only five Indian visitors a year came to Australia from 1905 to 1923, with no spouses. In 1911 of the 3698 "Hindoos", the majority were Hindus. Despite being British subjects, they were denied equal status, even land leases. ${ }^{10}$

\section{The Modern Townwallas The activist Hindu \\ In 1914 a Hindu activist, Totaram Sanadhya, visiting from the Fiji colony, received the}

proverbial welcome: "All black; have you got no soap?" "Sanadhya commented on the lack of community cohesion or religious identity among the Indians scattered in different parts of the country. Most Indians, Hindus among them, appeared to survive by inter-marrying and assimilating with the host society. The assimilationist practices in Australia have been blamed for keeping alive the "white-as-snow" ethos, that among the indigenous inhabitants included contrived mixed mating, dislocation of children, and mission confinements.

The agitations in 1923 of a visiting Indian diplomat and Hindu-rightist, Srinivasa Sastri, over the plight of local Indians, found support with the Council of Churches. This won them electoral franchise, pensions, and some concessions. But Sastri also reviled the great heroic symbol of the Indian diaspora, viz. Gandhi, pouring scorn on the "philosophic anarchy of the fervent fellow believer lost to an extremist Hindu cause"! Prejudices about the religious characteristics of the Indian were reinforced in the Australian psyche through Sastri's imagery of the "plucky little bloke in loincloth" and the bizarre practices of Gandhian Hindus. Even the cremation rite witnessed by many in the outback aroused allusions to suttee (sati or "widow-immolation"). ${ }^{12}$

\section{The Post-Independence Hindu Settlement \\ Post-colonial professional Hindu}

By the 1950 s the migrant community from the subcontinent was just too sporadic and scattered for a sense of ethnic-religious identity to grow. The 1954 census recorded 2647 Indians in the vast nation. With the end of World War II and the subcontinental Independence, immigration to Australia was open only for those with over $50 \%$ European blood. The late 1950s saw a slight increase in the number of Hindus opting for Australia rather than for England, the United States, and Canada. What attracted most was certainly not the promises of an open - environment where religious aspirations 
could be freely pursued. Instead, for many modern secular Hindus, the sixth continent appealed as a safe refuge from the religious orthodoxies and caste-ridden life back in the subcontinent. When packing their tin-chests, the emigrants asked: "What can we leave behind?" It might occur to them later that they have left behind some important ingredient of their identity.

After 1965, when the "White Australia" policy was officially dropped, the reception of immigrants changed, although reservations about admitting people with "different standards of living, tradition and culture" did persist. The overall image of Australia too had changed dramatically, from an open rural land to an industrializing, developing nation with professional opportunities. Thus while the 1961 Census recorded a total of 4,047 Indians, by 1971 there were 22,930 . The number nearly doubled in the $1980 \mathrm{~s}$, reaching 41,730 by 1981 , and some 50,000 in 1986. By 1991 the India-born population in Australia was 61,602 and by 1996 close to one lakh $(100,000)$. The figures of course include people of a wider religious orientation and also of European descent born in India. ${ }^{13}$ However, $15 \%$ of Indiaborn Australians in the 1996 Census are shown as Hindus (two-thirds being Christians, $6 \%$ Sikhs, and the rest registered an assortment of faiths or no-faith, or Parsis, and Jains). And they make up 31\% of all Hindus in Australia, i.e. 20,927 of $a$ total of 67,270 .

Professional Hindus are drawn from India and Sri Lanka, with increasing numbers arriving from other parts of the world. Hindus living in other former colonies began to migrate to Australia as well: from Malaysia and Singapore, Fiji, Mauritius, the United Kingdom, New Zealand, the southern and eastern African states, and most recently Hong Kong. Two recent Fijian-led military coups in the late 1980s, and political upheavals in Sri Lanka and some African states, increased the number of Hindus seeking to leave their adopted homes, and many looked to Australia, although a greater majority from these troubled regions have settled in Canada.

Taking the 1986 census as an example, 21,500 identified as Hindus (which includes European converts to Hinduism). The breakdown of overseas Hindus by country of birth was given as the following: India $35.7 \%$; Fiji 21.5\%; Sri Lanka 11.0\%; Malaysia 7.1\%, U.K. $4.3 \%$, South Africa $3.8 \%$, New Zealand $2.5 \%$, other $14.1 \%$ (this comprised Hindus from other states of Africa, Southeast Asia, North America, Europe, and the Arab regions). $74 \%$ of overseas-born Hindus arrived between 1967 and 1976. Among Australian-born Hindus 28\% indicated Indian ancestry, $25 \%$ reported British ancestry, $12.2 \%$ Australian ancestry, and the rest other ancestry. 14

These Hindus arrived with their cultural, linguistic, and religious links with India or Sri Lanka still intact. Hence the birth-place of the parents of all Australian resident Hindus in 1996 census is $43 \%$ for India (while, recall, only $35 \%$ have come directly from India). Hindus from Fiji made up 15,409 of the approximately 46,000 nonIndia born from a total of 67,270 Hindus. These disparate Hindus also came with more money, and quickly found themselves in well-salaried positions, choosing to live in select Anglo suburbs. The contribution of Hindus from these regions toward forging a distinctive religious identity in Australia cannot be overlooked.

It is estimated that by now, March 1998, there are some 75,000 Hindus in Australia, $20 \%$ of whom are Australia-born.

Age profile

Forty-two percent of Hindus are in the 25-44 age group (compared to $30.8 \%$ for all residents), equal between males and females. Most children are under 15 years of age, and fewer adults are over 65 , or widowed. The majority are married: $77 \%$ of women by 30 . The divorce or separation rate is low as is de facto relationship (although -increasing for Australian-born Hindus). The 
common family size is two children.

\section{Education}

Hindus show high levels of educational achievement. $21 \%$ have at least a bachelor degree and a further $12 \%$ have graduate qualifications. Hindu men have a higher level of education than women; but more Hindu women have university degrees than the Australian Ms Average. Indian and Sri Lankan born immigrants rank highly in postsecondary education after Jewish and Chinese groups. But Hindus do badly in skilled vocational qualifications, largely because of their concentration in the academic and professional sectors. They exhibit high levels of motivation, largely due to the postcolonial legacy to "succeed where the master once had ruled", backed by a heritage of traditional learning. The secondor third-generation Hindus go on to universities, but do not opt to become doctors, psychiatrists, surgeons, academics, and engineers with the same earnestness as their parents did. Perhaps this is a sign of the post-postcolonial reversal.

Unemployment among Hindus is relatively low and they tend to be employed in more demanding professions and managerial areas. However, since 1986 the situation has changed somewhat, with an increase in migrants of Indian descent from different regions and people with lesser skills or with farming and trade experience. Even professionals and highly qualified Hindus have during the recession decades sought employment as tradesmen, machinists, gardeners, and public-tram conductors. ${ }^{15}$

\section{Income}

Over one-third of the Hindus are professionals or paraprofessionals. Most earn between 35,000 to 70,000 Australian dollars annually. ${ }^{16}$ The higher bracket earnings render Hindus among the most affluent group of all South Asian immigrants. This is reflected also in the extent of support Hindus provide to community organization or building temples.

\section{Language}

Hindus are by and large conversant in a variety of languages, depending on their country or region of origin. 43,528 say they speak Hindi, 24,330 English-only, 24,790 speak Tamil, there are even 226 Chinese speakers among them, 1200 speak Bahaasa (Malay-Indonesian). So bilingualism is a common characteristic of the modern Hindu anywhere. More Tamils than Hindi-speakers use their native language in the home. The other major language groups represented comprise, Delhi-Hindustani, Gujarati, Marathi, Konkani, Bengali, Malayali, Kannada, Punjabi, and various dialects of Hindi (bhojpudi, Fiji-boli, and Bombay bhel-puri).

\section{Spiritual and Temple Culture}

Twentieth-century Hindu migration elicits radically different perceptions and responses to the challenges that previously faced the 19th-century counterparts. Both internal and external factors have contributed to the change and continuity, paving the way for a distinctive religio-ethnic identity to emerge. Multicultural Hindu

The diversity of regional, linguistic, and historical backgrounds of Hindus, of course, adds to the complexity of the baggage each group carries with it to a distant shore. The migrants from India and of South Asian descent, or ascent, who would otherwise call themselves Vaishnavas, Śaivas, Śaktas, Lingāyats, bhaktas, or Vedāntins, readily identify themselves as "Hindus" (thanks to the British colonialists who transformed the Persian appellation for people beyond the Sind range). These "Hindu" migrants in recent years have borne the burden of preserving their respective traditions, and participating on platforms of multiculturalism, or interfaith meetings.

Unlike western religions, Hinduisms' abhāvasas are said to preclude fixed doctrines, tight-knit structures, hierarchical governance, and a rigid organizational base with ecclesiastical control, etc. Nevertheless, the monotheistic model provided by the Semitic trinity has captured the imagination 
of modern Hindu leaders, seeking political gains in India, and moral and material support in the wider diaspora. (The coinage "diaspora" itself being a borrowed notion from Hellenized Judaism.) In Australia that impact is increasingly evident, while it tends also to eclipse the humble beginnings of a more diffused communitarian base aimed at continuing Hindu practices and culture locally.

\section{Hindu gurus}

In the 1960 s and 1970 s gurus with a strident universalist outlook and a narrower neoHindu disposition embarked on a world mission. An assortment of gurus, yogis, bhogis, bābās, swāmīs, Vedāntists, tāntrikas, self-anointed goddesses, spiritual mothers, and mute avatars, began seeking converts in Australia as well. They included Paul Brunton, Mauni Sadhu, Meher Baba, J. Krishnamurthi, among others. But it was Swami Ranganathananda of the Ramakrishna-Vivekananda Mission, who since his 1964 visit helped found a firm Order, the Vedanta Society of N.S.W., drawing in resident Hindus as well. Maharishi :Mahesh Yogi of the TM movement gained a wider following in the larger community, establishing a closed structure for its purported quasi-spiritual goals.

In 1969 came the Hare Krishnas, and over the next twenty years they built an extensive network of ISKCON temples and schools in the major cities, and a living-in farming community also. Before they built their own temples, Hindus payed regular visits to the ISKCON temples.

The Siddha Yoga syndicate arrived in 1970 with Baba Muktananda, after his U.S. debut. Its popularity grows despite posthumus allegations of intimate encounters between the good Baba and some Australian women disciples (New Yorker, February 1995). His self-proclaimed successor now reigns over the multi-million dollar Siddha Yoga empire that stretches between New York, Upper Thane, and Melbourne. But local Hindus nowadays seem not to patronize these inner-SYDY-ashrams.

Followers of Guru Maharaji, Osho Rajneesh, Swami Venkatesananda, Satyananda Saraswati, and the WoodstockRock Swami also established ashrams. Swami Sivananda's followers promoted an integral ecumenism, followed up later by Dom Bede Griffiths, who attempted infusing aspects of Hindu practices into Christian worship, during his two Australian visits.

Two gurus have commanded a sizeable following in the resident Hindu community. Swami Chinmayanda, with his flamboyant erudition of the Vedānta, appealed to Hindus with a more conservative bent. Before his death in 1995, he had publicly endorsed the Hindu tirade against Muslims in Ayodhyā.

The other is Sri Sathya Sai Baba. Not without his own controversies in India, Sathya Sai Baba wields considerable popularity through his devotional teachings, miracle healing, educational activities, and speciality medical hospitals. His devotees hold regular weekly bhajan gatherings in the major cities and most towns around Australia, and coordinate educational activities and services for the aged.

Such incentives have inspired other Hindu community groups towards establishing vernacular baal-vikas (children's outside-of-school classes) and even hospice centres for the aged. Some wealthy Hindu families in Melbourne and Sydney have provided funds or lent their commercial premises for community activities, focusing on welfare and counselling help. Working closely with volunteer groups such as the Salvation Army, the Brotherhood of $\mathrm{St}$ Laurence, and the Sisters of Charity, some sanguine room is created for interreligious activities that may go beyond feeding the needy, meals-on-wheels, and other charitable work. "Who on earth is your orange-clad leader?" "Come (and) find out", invited someone, or so it is reported.

\section{The Organized Temple Hindu}

In each of the major cities in Australia - Hindus have organized themselves into 
Hindu societies and erected temples. The initial impetus almost invariably comes from north Indian Hindus. But the religious outlook and practices of this group appear to the southern Hindus, especially Tamils, to be limited in scope and compromised by the pressures of modern life. This scenario has been repeated across three major metropolitan regions, notably, Sydney, Melbourne, and Perth, creating both an atmosphere of cooperation and tension, even rupture. Tamil groups then clamour to assume responsibility for completing the temple complexes and instituting attendant rites grounded in Sanskrit Ägamas.

Before the mid-1970s, there was an absence of spiritual fellowship among the Hindus, apart from ad hoc gatherings or retreats around visiting Swamis. Solemnizing "rights of passage", such as marriage and death, via Vedic rites was even difficult. However, a catalyst brought home this desperation.

The spouse of a Sri Lankan Hindu man, who had suddenly died while shopping in Sydney, enquired after proper final rites, but without success. The community then moved to establish a venue for religious and cultural practices, in a decrepit old church building, with the help of voluntary functionaries. Shortly afterwards, the Sri Venkateswara Hindu Temple Association, echoing Pittsburgh, erected a charming edifice in "virgin" surroundings, that blended the aesthetics of traditional south Indian temple with the natural reserves. ${ }^{17}$ Tamil priests and financial support came from the Tirupathi-Tirumala Devasthānam (TTD) in Andhra Pradesh. Largely patronized by south Indian and Sri Lanka Hindus, the temple is an elegant symbol of Hindu accomplishment in Australasia, inspiring similar projects in other states.

A group of upper caste Gujarati worshipers of Siva, under the aegis of the Indian Heritage Research Foundation, has built the world's first "Underground Hindu Temple". The major deity housed is Śri Vishvanātha, after the famed Lord of
Banaras. The community had to initially lobby the shire council to overcome opposition, mostly from Christian denominational groups. 18

Meanwhile, foundations for a third temple have been laid in the Sydney metropolitan region by Tamil and Telugu Śaivites from Malaysia and similar regions. The modest temple dedicated to Murugan or Subramaniya is pending completion.

In Victoria, a Hindu Society was incorporated in the late 1970s. A major temple project, incorporating adjacent shrines to Vishnu, Śiva, and Devī under one massive canopy, was eventually built costing over one million dollars. Again, help came from the TTD. However, contentions within the temple committee, amidst suspicions of Jaffna connections, drove Hindus from Malaysia and other regions to build an alternative Vinaya (Ganesh) temple in the outer suburbs. North Indian Hindus likewise left to de-establish a permanent structure, preferring instead the weekend home or hired-hall based religious meetings and ceremonies as needed. The Ārya Samājis among them were doubly pleased as they have no need for a temple, happily offering the homa or havans in various Ärya homes. Lay members within the community gained registration as religious celebrants and performed the priestly functions wherever as part of their calling.

A third temple is to be added to Melbourne, namely, a Durga Maa temple proposed by the Sri Durga Bhajan Mandali Inc. A parcel of land has been purchased. Like this Mandali, there are a number of informal groupings around one or other of the neglected Hindu gods or goddesses, with aspirations toward cultural advancements in their own terms. Some members are anxious that the larger temple complexes have become routinely ritualistic and impersonal, neglectful of diasporic needs, in particular education in the vernaculars and transmission of values, Hindu mores and customs to the younger generation, although this is not true of all local Hindu temples. 
Nonetheless, it is in this absent space that not only radical Tamil groups but also Hindu organizations, such as the Vishwa Hindu Parishad (VHP), occasionally with the Rasthriya Swayam-Sevak Sangh (RRS) (or its representative in Australia, Hindu Rasthriya Sewak-Sangh), and even the Bharatiya Janata Party (BJP) step in with promises to promote just such causes they too claim to stand for. The sway towards the Hindu Right is likely also to bring Hinduism into a somewhat more confrontational stance with the larger host society or its more liberal platforms. Indeed, alliances have already been drawn in the politically-hot centre of Australia between a largely whitecollar Hindu group and the family of the present Prime Minister of Australia, who is one of the more conservative leaders in the Western world, presently on the warpath to abolish native entitlements for the Aborigines across a number of sensitive areas.

In the nation's capital territory, Canberra, there are two different Hindu collectives, namely, Mandir Society of Australia and the Hindu Temple and Cultural Centre of A.C.T. Both societies are controlled by north Indian Hindus even as they each declare allegiance to the VedāntaBhakti traditions, and constructed their own Hindu temple on the outskirts of the capital. Clearly, unlike other Western cities, the division within the Canberra Hindu community is not along the north and south Indian divide, but rather reflects personal and ideological differences prevalent both in India and in this nation's capital.

North Indian Hindus in Australia have growing links with the Hindu Right, which is also a cause of tension and split among the Hindus. Anti-Muslim sentiments exist among the Hindus, although not expressed in public. Just as at one time forums for interreligious interactions were being hogged by radical Sikh elements, nowadays representatives from Hindu groups earnestly attempt to foster "dialogue", so as to stamp their own authority on all things Hindu (or even Indian) and to underscore the pragmatic affinities between Hinduism and Judeo-Christianity against the alleged heterodoxy of Islam. Such is the price for global interreligiosity or "radical apluralism"! 19

\section{Conclusion}

As with all people who leave their homelands for distant promises, Hindus in Australia have endured many hardships, persevered despite social and cultural alienation, and encountered racial prejudices and disempowerment because of their colour or religious background. Only in recent times, with the demise of colonialism, has the community been able to resist pressures of an assimilationist ideology that all but erased their earlier distinctive presence in the vast expanse of the Australian landscape. This was exacerbated by the numerically small and tightly controlled migration with specific biases, such as gender preference and labour-base.

The Indian and especially the Hindu community in Australia has been slow in celebrating its ethnic identity and internal differences, or evolving a selfconscious ethos with a heritage of values and customs which it could pass on to the next generation. There are always tensions for the immigrants, between their cherished expectations and the awareness of their "otherness", in the naya-duniya ("new world"), which is at the forefront of the "modern" or rather "Western" world.

Nevertheless, it is significant to note that after a period of gestation the amorphous collective perceives the need for a firm Hindu cultural base and temples. Imagining the temple presents a pretext for the coming together of Hindus in the diaspora. As a signifier for prescribed ritual and interiorized practices, the temple enables greater confidence in one's practices. As a permanent presence, the temple makes the Hindu identity publicly visible. It also provides a matrix for ironing out differences - and tensions among the different sectarian 
and regional groups, or alternatively to bolster political interests of their respective homeland movements.

With at least one temple in every major city and a community or bhajan-mandali in each remote town, Hindus can now readily seek out their fellow affiliates, share auspicious events and ceremonies, call on kindred souls to help with wedding arrangements, and organize baal-vikas so that their children can learn a smattering of the home-spoken lingua and tracts from mythological and moral doctrines (i.e. Krishna's life, karma, rebirth, and Ayodhyā). They may even seek advice on the proper execution of the final rites for one of their deceased, and witness the same, albeit under the closed canopy veiling the rapid snatch by the smokeless electric Yāma. (There is however a lobby calling for a return to the erstwhile ghee-fired eucalyptuspyre, but for stringent health regulations.)

In the broader Australian society, the Hindu temple, along with the smoke from the Ārya Samāji fire-oblation, symbolizes the struggles of a multicultural and ethnically plural ethos. The resulting interaction of cultures and fusion of discordant horizons promises to produce a society that is critically tolerant, more enlightened, artistic, and truly democratic or so it is hoped by some leaders of the nation. ${ }^{20}$ Religious diversity is a reality that Australia can no longer ignore, despite the occasional anxiety to preserve the dominant Anglo-Celtic-Christian identity against the challenges of pluralism, and despite the growing lag in critical intellectual reappraisals within the religious communities themselves. But it has taken some two hundreds years to reach this sagacity, in which the contributions of the diasporic Hindus, along with Jains, Sikhs, Parsīs, Muslims, and Buddhists from South Asia and elsewhere, have been quite significant.

\section{Notes}

1. In 1996 I published a book on Hindus and
Sikhs in Australia: A religious community Profile (Canberra: Bureau of Immigration and Multicultural and Population Research, Government of Australia, 1996); in 1997 John Hinnells included my chapter on "The Australian South Asia Diaspora" in his newly revised, edited, and reworked $A \mathrm{New}$ Handbook of Living Religions (Oxford/ Cambridge, MA: Blackwell Publishers, 1997, pp. 728-55). Unmarked references to sources and information are from these works.

Since then the data from the 1996 Australian Census have been trickling in and I am making an effort to incorporate them into my on-going narratives. Since I received requests for two articles at about the same time from different ends of Canada, and without thinking twice, accepted to write them, although with different focus, there is some overlap between this essay and the article solicited for the Proceedings of the International Conference on Hindu Diaspora, Concordia University, Montreal. (I have not been informed if indeed my article will be used.) I also wish to thank the Christian Research Centre in Melbourne for once again helping me out with religions data from the 1996 Census.

2. P. Bilimoria, Hinduism in Australia: Mandala for the Gods (Melbourne: Spectrum with Deakin University Press, 1988a), note 4-6, and pp. 16-17. Historians of Southeast Asia disclaim any evidence that suggests that Indian contact went further, or to the Australian continent, in ancient times.

3. A. T. Yarwood, Attitudes to Non-European Immigration Problems in Australian History (Melbourne: Cassell, 1968) p. 12; see also Marie de Lepervenche, Indians in a White Australia: An account of race, class and Indian immigration in eastern Australia. (Sydney: Allen \& Unwin, , 1984) p 36; see also R. Jayaraman, "Indians" in James Jupp (ed.) The Australian People: An Encyclopedia of the Nation, Its People, and Their Origins. (Sydney: Angus Robertson, 1988) pp. 542-545.

4. M. Willard, History of the White Australia Policy to 1920. (Melbourne University Press, 1923, 2nd edn. 1967), p 4. Further discussion in P. Bilimoria and R. Ganguly- 
Scrase, Indians in Victoria (Australia), (Melbourne: Victorian Ethnic Affairs Commission and Deakin University, 1988b), pp. 18-32.

5. Jayaraman (op cit); Willard, p. 7; Bilimoria et al, 1988b, (op cit).

6. Ernstine Hill, The Great Australian Loneliness (London: Jarrolds, 1937) p. 281

7. Australian News, 1 May 1893.

8. Pammamull family archives (personal access). Cf. Watammull in Honolulu, who are also renowned for their patronage of Indian culture in the diaspora.

9. Presbyterian Minister's defence in 1901 of "the noble ideal of a White Australia snow-white Australia if you will" (in Bilimoria, 1988b, p. 33). And, Alfred Deakin, later Premier of Australia (after whom my University is named), who had visited India and was a spiritualist by persuasion, although he gave exemptions to Indian travellers and students; see also Alfred Deakin, Temple and Tomb in India, (Melbourne: Melville, Mullen \& Slade, 1893); and Allan Walker, Plan for $a$ Christian Australia (Melbourne: Methodist Church of Australia, 1955) outlines the history of this movement and its persistence in the church, especially the Methodists.

10. de Lepervenche (op cit) pp 66-9.
11. Bilimoria et al (1988b) pp. 27-30.

12. ibid.

13. Extracted from 1991 Census of Population and Housing, State Comparison series ABS Catalogue No. 2731.0 and other comparable catalogues on birth by country, languages, etc.

14. Bilimoria, $1988 \mathrm{~b}$, pp. $78-86$.

15. Bilimoria, 1988a, pp. 59-60.

16. 1996 figures from the Australian Bureau of Statistics Census Profile.

17. Bilimoria, 1988a, p.59-60.fg.

18. "Hinduism Today", June 1991, p.4. and Prem K. Misra, "Report on Proposed Sri Vishvanath Temple at 201 Eagleview Road, Minto, N.S.W." (Parmarth Educational Centre, Indian [Hindu] Heritage Research Foundation, 1990).

19. I have discussed the situation of the HinduChristian dialogue earlier in my report in Hindu-Christian Studies Bulletin, vol 7, 1994, pp. 31-18; also in my article, "A problem for radical (onto-theos) pluralism,", in Sophia, vol 30 no. 1, 1991, pp. 21-33; and "Hindu-Christian Dialogue - some thoughts from the diaspora" (unpublished).

20. BIPR Bulletin, Number 9, July 1993 (Canberra: Bureau of Immigration and Population Research), p. 16. 